\title{
SALMONELLOSIS IN NORTHERN IRELAND, WITH SPECIAL REFERENCE TO PIGS AND SALMONELLA-CONTAMINATED PIG MEAL
}

\author{
BY K. W. NEWELL, R. MaCLARIN \\ Department of Social and Preventive Medicine, Queen's University, Belfast \\ C. R. MURDOCK, W. N. MacDONALD \\ Northern Ireland Hospitals Authority, Central Laboratory, Belfast \\ AND H. L. HUTCHINSON \\ Veterinary Division, Ministry of Agriculture, Northern Ireland
}

\section{INTRODUCTION}

Northern Ireland is politically a part of the United Kingdom, and it shares with England and Wales many economic and social factors related to the occurrence of salmonellosis. A food shop in Belfast appears to be little different from one in London, and many of the same products produced by the same firms appear on the shelves. Similarity in the form of the Health Service, the notification of food poisoning, and the presence of laboratory services would lead one to expect similarity in the apparent prevalence of salmonellosis and the biochemical and serological salmonella types isolated. Because there are so many of these common factors, any differences in salmonellosis may be useful in suggesting new vehicles of spread and possible methods of investigation.

Table 1 shows the number of salmonella isolations from human sources in Northern Ireland from 1951-58, and Table 2 shows the number of incidents notified or known to the laboratory in 1952 and 1955, and similar information for England and Wales. In Northern Ireland the number of incidents per million people has decreased, due largely to a fall in the number associated with Salmonella typhimurium, while in England and Wales the number of incidents per million people increased without a change in the proportions due to this type. Reports $(1950 a, b, 1951,1954,1955 a, b, 1956)$ from England and Wales show that the percentages of all salmonella incidents due to Salm. typhimurium from 1939-44 were similar to the present proportions in Northern Ireland (i.e. 30-50\%), and then increased abruptly in 1945. The decrease in Northern Ireland has occurred gradually since 1951 .

These recorded incidents bear an unknown relationship to the true prevalence of salmonellosis, and this relationship may differ in the two areas. However, there were improvements in laboratory services and notification in both areas, and the changes shown in Tables 1 and 2 might indicate a real change.

This change cannot be adequately explained, although the imports of one major foodstuff in Northern Ireland decreased during the period and may be directly associated. Since 1945 England and Wales have imported large quantities of fresh, 
chilled and frozen meats, offals and manufacturing meats from Australia and New Zealand, and some of these products have been found to contain Salm. typhimurium. Hobbs (1957) describes the isolation of this strain from eight out of eighteen imported minced beef samples and from twenty-four out of 118 samples of frozen boneless veal. She also refers to the large Swedish outbreak of gastroenteritis described by Lundbeck, Plazikowski \& Silverstolpe (1955) which was subsequently found to be associated with imported frozen and boned meat.

\section{Table 1. Salmonella in Northern Ireland}

(Number of isolations from human sources.)

\begin{tabular}{|c|c|c|c|c|c|c|c|c|c|}
\hline \multirow[b]{2}{*}{ Salmonella type } & \multicolumn{9}{|c|}{ Year } \\
\hline & 1951 & 1952 & 1953 & 1954 & 1955 & 1956 & 1957 & (first & $\begin{array}{l}1958 \\
8 \text { months) }\end{array}$ \\
\hline All salmonella & 94 & 80 & 60 & 56 & $123^{*}$ & 39 & 48 & & 56 \\
\hline $\begin{array}{l}\text { Salm. typhimurium } \\
\text { (\% of total) }\end{array}$ & $\begin{array}{c}79 \\
(84)\end{array}$ & $\begin{array}{c}64 \\
(80)\end{array}$ & $\begin{array}{c}47 \\
(78)\end{array}$ & $\begin{array}{c}43 \\
(77)\end{array}$ & $\begin{array}{c}53 \\
(43)\end{array}$ & $\begin{array}{c}15 \\
(38)\end{array}$ & $\begin{array}{c}11 \\
(23)\end{array}$ & & $\begin{array}{c}19 \\
(34)\end{array}$ \\
\hline $\begin{array}{l}\text { Other salmonella } \\
\text { (\% of total) }\end{array}$ & $\begin{array}{c}15 \\
(16)\end{array}$ & $\begin{array}{c}16 \\
(20)\end{array}$ & $\begin{array}{c}13 \\
(22)\end{array}$ & $\begin{array}{c}13 \\
(23)\end{array}$ & $\begin{array}{l}70^{*} \\
(57)\end{array}$ & $\begin{array}{c}24 \\
(62)\end{array}$ & $\begin{array}{c}37 \\
(77)\end{array}$ & & $\begin{array}{c}37 \\
(66)\end{array}$ \\
\hline $\begin{array}{l}\text { Salm. heidelberg } \\
\text { (\% of total) }\end{array}$ & $\overline{(0)}$ & $\overline{(0)}$ & $\overline{(0)}$ & $\overline{(0)}$ & $\begin{array}{c}35 \\
(28)\end{array}$ & $\begin{array}{c}11 \\
(28)\end{array}$ & $\begin{array}{c}32 \\
(67)\end{array}$ & & $\begin{array}{c}10 \\
(18)\end{array}$ \\
\hline
\end{tabular}

* Twenty-two isolations were from an outbreak of Salm. newport. If these are considered to be one incident, the figures become: All salmonella 102, Salm.typhimurium 53 (52\%). Other salmonella $49(48 \%)$, Salm. heidelberg $35(34 \%)$.

Information supplied by the Northern Ireland Hospitals Authority, Central Laboratory, Belfast.

Table 2. Salmonella incidents in England and Wales and Northern Ireland, 1952, 1955

\begin{tabular}{|c|c|c|c|c|}
\hline \multirow[b]{2}{*}{ Year } & \multicolumn{2}{|c|}{ Northern Ireland* } & \multicolumn{2}{|c|}{ England and Wales $\dagger$} \\
\hline & $\begin{array}{c}\text { Salmonella } \\
\text { incidents/ } \\
\text { million } \\
\text { people }\end{array}$ & $\begin{array}{l}\text { Percentage } \\
\text { incidents } \\
\text { due to Salm. } \\
\text { typhimurium }\end{array}$ & $\begin{array}{c}\text { Salmonella } \\
\text { incidents/ } \\
\text { million } \\
\text { people }\end{array}$ & $\begin{array}{l}\text { Percentage } \\
\text { incidents } \\
\text { due to Salm. } \\
\text { typhimurium }\end{array}$ \\
\hline 1952 & 80 & 84 & 46 & 75 \\
\hline 1955 & 32 & 38 & 80 & 79 \\
\hline
\end{tabular}

* (Northern Ireland information obtained from the Northern Ireland Hospitals Authority, Central Laboratory, Belfast; the Report of the Minister of Health and Local Government, Northern Ireland, 1952, 1955; the Annual Reports of the Medical Officers of Health, County Councils and County Borough Councils.)

$\dagger$ Number of incidents given in Report (1954) and Report (1956).

In Northern Ireland there were large imports of meat products from Australasia during the period of meat rationing, but after 1954 these decreased and continued at very low levels as Northern Ireland resumed her place as a meat exporter. There were no marked changes in imports of meat from this source in England and Wales at these times.

Salm. typhimurium is also found in other products imported into both areas (e.g. egg products), but it has not yet been possible to show by 'phage-typing' 
methods that the particular 'phage types' of this organism associated with contaminated meat products, are uncommon in Northern Ireland.

Salm. heidelberg was first isolated from a human case in Belfast in September 1955. It had been isolated in England and Wales in 1953 (eleven incidents), 1954 (sixteen incidents) and 1955 (seventy-seven incidents) (Reports, 1955 $a, b, 1956$ ), in the United States in 1954 (MacCready, Reardon \& Saphra, 1957), in Germany in 1953 (Marcuse, Henze \& Pohle, 1957), and in other countries.

Thirty-five isolations were made from human cases in Northern Ireland in the autumn of 1955 and since then it has become one of the common salmonella types found to be associated with human cases of gastro-enteritis.

A field investigation of the human cases in Northern Ireland suggested that pork products could possibly be the vehicle, although the products used in the affected households came from a variety of sources and were processed in many different factories. The lack of grouping to one factory or area made it difficult to assume that pork products were the vehicle.

The experience with this salmonella type in different parts of the United Kingdom emphasizes again the possibilities of comparing the findings in two closely related areas. England and Wales showed the presence of Salm. heidelberg 2 years before it was found in Northern Ireland. (If the reverse had occurred it might have been suspected that a food product produced in Northern Ireland had become contaminated and exported.) This finding alone suggested that it would be useful to make a detailed comparison of food products, animal food products, and food processing substances imported, by country of origin, at this period of time. The number of possible products which would show this time interval would not be great and the list could be made smaller by import information from other countries whose findings with regard to contamination of food products with salmonella organisms are known.

Since the war there have been many complaints from farmers in Northern Ire. land of 'scour' in pigs. Although a few pigs in a small number of outbreaks were found to be excreting Salm. cholerae suis, many of these outbreaks have been thought to be due to a dietary imbalance. With this exception, salmonella infection in pigs has been thought to be uncommon, although studies in England and Wales (Scott, 1940; Report, 1947; Report, 1955c), South America (Hormaeche \& Salsamendi, 1936) and the United States of America (Galton, Smith, McElrath \& Hardy, 1954) suggest that an infection rate of $30 \%$ would not be surprising.

The natural pathogenicity of the different salmonella types varies considerably and it would appear that in a very considerable proportion of the pigs excreting salmonella organisms the infection is confined to the gut and the mesenteric glands, and symptoms do not occur. Edwards \& Bruner (1943) showed, for instance, that whereas Salm. cholerae suis is often a blood-stream infection in animals, the kunzendorf variety does not invade and the infection remains localized; even the mesenteric glands may not be involved. Nevertheless, from the point of view of the infectivity of the animal this differentiation may not be so important.

In the Report (1947) there was good evidence to indicate that many of the salmonella infections might be related to infective feedingstuffs and the recent 
studies by Rohde \& Bischoff (1956), Hobbs (1957) and Walker (1957) suggest that the various salmonella organisms so frequently isolated from fish and bone meal used for pig feedingstuffs might be related to salmonella infections in pigs. Up to the present this, as far as is known, has not been accomplished and the investigations described in this communication were designed with this object in view.

It was decided to examine bacteriologically the caecal contents of a number of freshly slaughtered pigs which could be traced back to their farm of production. An examination of the remaining pigs on these farms, and of the feedingstuffs used at the relevant times, might indicate a chain of infection from a salmonellacontaminated product used in pig meals to a food eaten by humans.

\section{MATERIALS AND METHODS}

The investigations described here began in the slaughterhouse and, when a salmonella organism was isolated, they continued as a combined bacteriological and epidemiological study at the farm from which the animal came. Rectal swabs were collected from a representative number of live pigs on each farm visited, and samples taken of the various foodstuffs given to the pigs. On one occasion it was possible to visit the mills preparing the foodstuff and to examine separately some of the ingredients which were mixed to form the final product. Information was obtained from the farmers concerned about the management of the farm, past and present illness among their stock, the types of pig meal used and other relevant points.

The slaughterhouses selected for the investigation were those attached to two large bacon factories where about 4800 pigs were killed each week. One of these factories, in addition to curing bacon, processed and packed pork fillets and sausages.

Both factories were more than 25 miles from Belfast and obtained pigs from scattered rural districts where the use of swill from urban sources was unlikely or impossible. In the main the pigs came from small mixed farms, but there were a few larger specialist producers. The records from one factory showed that $52 \%$ of the producers delivered less than five pigs per week; the largest number from any one farm in one week was ninety. Most of the pigs were brought to the factory by lorry and the distances from the farms were so small that a journey of more than $2 \mathrm{hr}$. was exceptional. No food was supplied on the journey or at the lairage, but the pigs had access to unlimited water.

The lairages were empty on Saturday and Sunday, when they were cleaned and washed. There was little holding after delivery from the farms as 800 of the 1100 pigs arriving on Monday at each factory were slaughtered on that day. The remaining 300 pigs were delivered after $4 \cdot 30$ p.m. and they were slaughtered on the Tuesday before 2.00 p.m. The additional 500 pigs killed on Tuesday were delivered on that day. The short holding time before slaughter decreased the chances of crossinfection which were emphasized by Galton et al. (1954) and McDonagh \& Smith (1958).

The pigs examined were selected on Tuesdays with no knowledge of their source, 
and the sampling was spread over a working day so that pigs from Monday and Tuesday deliveries would be included in the sample group.

The method of killing, bleeding and processing the pigs was similar to that described by McDonagh \& Smith (1958).

Two series of slaughtered pigs were examined bacteriologically. In the first (comprising 389), after evisceration a knife hole was made in the caecum large enough to admit a cotton-tipped nickel-chrome wire throat swab without touching the sides of the opening. The swab was inserted into the caecal contents, withdrawn and then replaced in its glass container marked with the pig reference number. The swabs were sent to the laboratory for examination on the same day. Each swab was inoculated directly on to plates of Wilson \& Blair's medium, as modified by Hobbs, King \& Allison (1945), and Leifson's medium (1935) to which $1 \%$ sucrose had been added. The swab was then immersed in Selenite F enrichment medium (Hobbs \& Allison, 1945) from which subcultures were made on plates of the selective media after $24 \mathrm{hr}$. incubation. Suspicious colonies were picked off and tested for their biochemical and serological reactions.

For the second series (100 pigs) a similar procedure was followed for the collection of the swab sample. In addition, the neck of a small sterile bottle was inserted into the hole in the caecal wall and a specimen of the caecal contents squeezed into the bottle. Thirty of the carcasses from this series were followed into the cool room, and after they had been graded, samples of meat were removed, observing precautionary measures against cross-contamination. These samples were taken from the muscular part of the diaphragm and the pelvic part of the obturator muscleportions used in this factory for sausage meat. Parts of these and other carcasses from the day's production were processed for sausage meat the following day and twenty samples of the sausage contents were taken from the sausage machine, in series, during the relevant $12 \mathrm{hr}$.

The bacteriological examination of the caecal swabs and the faeces specimens in the second series followed the procedure outlined for the first series. The samples of meat and sausage contents were inoculated directly into Selenite broth and incubated for $24 \mathrm{hr}$. at $37^{\circ} \mathrm{C}$. before being plated out on the selective media described above.

Rectal swabs taken from the live pigs on the farms investigated were examined in the same way as the caecal swabs.

The various pig meals or poultry meals were examined by first adding $50 \mathrm{~g}$. of the meal to $250 \mathrm{ml}$. Selenite F enrichment broth. After mixing, the inoculated medium was incubated for $24 \mathrm{hr}$. at $37^{\circ} \mathrm{C}$. and then plated out on the two selective media. Any salmonella-like colonies were picked off for further examination.

\section{RESULTS}

\section{Slaughterhouse examinations}

Apart from the presence of tuberculous mesenteric glands (of which an accurate record was not kept) there were no naked eye abnormal post-mortem findings and no evidence of enteritis in any of the pigs examined. 
In the first series, 389 pigs were examined by means of caecal swabs only, and swabs from four of these pigs yielded salmonella organisms (Salm. banana (1), Salm. amager (1), Salm. worthington (1) and Salm. schwarzengrund (1)).

In the second series, 100 pigs were examined, but here, in addition to the caecal swab, the faeces in the caecum of each pig was cultured. From thirty of these pigs meat samples were taken from the carcasses, as described above. Six of the caecal swabs yielded salmonella organisms (Salm. meleagridis (1), Salm. orion (4) and Salm. senftenberg (1)), but twenty-three specimens of faeces were positive (Salm. essen (1), Salm. infantis (13), Salm. kentucky (1) and Salm. orion (8)) (see Table 3).

Table 3. Salmonella isolations from pigs and pig products at a bacon factory. Number of salmonella isolations

(In brackets the number of isolations per 100 specimens examined.)

\begin{tabular}{|c|c|c|c|c|}
\hline \multirow[b]{2}{*}{ Salmonella type } & \multicolumn{4}{|c|}{ Description of specimen } \\
\hline & Caecal swab & Caecal faeces & Meat & Sausage meat \\
\hline Salm. essen & - & 1 & - & - \\
\hline Salm. infantis & - & 13 & - & - \\
\hline Salm. kentucky & - & 1 & - & - \\
\hline Salm. meleagridis & 1 & - & 一 & - \\
\hline Salm. orion & 4 & 8 & 1 & 14 \\
\hline Salm. senftenberg & $\mathbf{1}$ & - & - & - \\
\hline $\begin{array}{l}\text { Number specimens } \\
\text { examined }\end{array}$ & 100 & 100 & 30 & 20 \\
\hline $\begin{array}{l}\text { Number salmonella } \\
\text { isolated }\end{array}$ & $6(6 \%)$ & $23(23 \%)^{*}$ & $1(3 \%)$ & $14(70 \%)$ \\
\hline
\end{tabular}

Only one sample of meat was positive and the organism was identified as Salm. orion. This salmonella sero-type was also isolated from fourteen of the twenty specimens taken of sausage meat in series from the sausage machine.

The difference between the results of caecal swab and faeces culture was very striking. It is a common experience of the medical clinical bacteriologist to find that faeces are superior to rectal swabs, but it is unusual to find the marked difference recorded here. The greatest difference between the two methods was the failure of the caecal swabs to distinguish the thirteen pigs shown to have Salm. infantis in the caecal faeces. This salmonella type may be more difficult to isolate from caecal swabs when it is present in small numbers and certainly the increased size of the caecal faeces specimens and the relatively larger inocula used would offer a better opportunity for its isolation, but there are probably other factors of importance which can not at present be adequately explained.

The 489 caecal swabs in the two series were collected and examined in the same way and can be grouped together. They were shown to contain ten salmonellae $(2 \%)$ and this can be considered to be the minimum salmonella infection rate in pigs from this area. The results from caecal faeces suggest that the rate which could be demonstrated by a number of sampling procedures may be ten times this figure. 


\section{Farm investigations}

Visits were made to the four farms identified as the producers of the four salmonella-infected pigs in the first series and also to a farm producing a pig infected with Salm. orion in the second series. The general condition of the farm was observed and bacteriological investigations were made upon rectal swabs from the remaining pigs, and of the feedingstuffs used.

\section{Farm $A$}

This farm, which produced a pig excreting Salm. banana, consisted of three scattered units within a 2-mile radius of a small town. The farmer owned 180 pigs, bought as weaners from local sources. There was a small number of beef cattle on one unit but no other animals and no dwelling houses were close to the pig pens. The farmer described a scour outbreak involving all his units 6 months previously. This had been unsuccessfully treated with antibiotics, but had slowly disappeared. There had been no evidence of illness in the 3 months preceding the present investigation.

Rectal swabs were taken at random from fifty of the pigs in the pens and fourteen samples of a proprietary pig-fattening meal from the store room. All the specimens taken on the farm were negative for salmonellae.

The proprietary meal contained Herring Meal from Denmark, Soya Bean Meal from Nigeria and Burma, Ground Nut Meal from French North and West Africa, and aureomycin, but none of the constituents were available for separate sampling.

\section{Farm $B$}

The pig, from which Salm. amager was isolated, came from a small farm run as a sideline by a lorry driver and containing eighty pigs bought locally as weaners. There had been no evidence of scour in the preceding 12 months. Rectal swabs were taken at random from forty-two pigs and nine samples of pig meal were collected. One swab showed blood and mucus but salmonella organisms were not isolated from this or any other of the rectal swabs.

Salm. amager and Salm. orion were isolated from two of the samples of pig meal. The meal, a proprietary feed, contained meat and bone meal produced in Northern Ireland and fish meal from South West Africa, but no antibiotics. Ingredients of the same batches as those used for the made up feed were not available for separate sampling at the mill.

\section{Farm $C$}

The pig yielding Salm. worthington was traced to a large modern mixed farm which bred pigs (200 pigs present) and also horses, dairy, fat and store cattle, sheep and large numbers of hens.

Rectal swabs, two of which showed blood and mucus, from thirty-one pigs were examined, and Salm. worthington was isolated from one swab. The pig feed was mixed on the farm and the constituents included a protein concentrate containing 
fish meal. Five samples of meal showed no salmonellae and four samples of concentrate of a different batch were also negative. Feedingstuffs for all the stock were mixed from many different constituents in the same building, using the same machinery. There were many opportunities for any one product to contaminate all feeds.

\section{Farm $D$}

Salm. schwarzengrund was isolated from a small mixed farm keeping pigs, dairy cattle and hens. One sow was used for breeding and her litters were supplemented by weaners bought locally. There had been no scour on the farm in the previous 12 months. At the time of our visit there were only twenty-two pigs with the sow, and rectal swabs were taken from all these animals. Four samples of the proprietary meal used were also collected.

Of the twenty-three rectal swabs salmonella organisms were isolated from eleven (Salm. infantis (8), Salm. bareilly (2) and Salm. schwarzengrund (1)).

Salm. infantis was isolated from three of the samples of meal and Salm. agama from the remaining sample.

One week's production of hen eggs (twenty-seven dozen) from this farm was examined. The egg-meat and the shell were examinsd separately in batches of eighteen eggs. Three of the eighteen batches of egg-meat contained salmonella organisms (Salm. infantis (1) and Salm. albany (2)), but none were found in any of the batches of shell. None of the fowls had any apparent illness.

Table 4. Salmonella (all types) found on farms marketing infected pigs

$\begin{array}{ccccc}\text { Farm } & \text { No. pigs } & \begin{array}{c}\text { No. meal } \\ \text { samples } \\ \text { examined } \\ \text { at farm }\end{array} & \begin{array}{c}\text { No. salmonella } \\ \text { isolated }\end{array} \\ \text { A } & 50 & \text { No. pigs positive } & 14 & 0(0 \%) \\ \text { B } & 42 & 0(0 \%) & 9 & 2(22 \%) \\ \text { C } & 31 & 1(3 \%) & 5 & 0(0 \%) \\ \text { D } & 23 & 11(48 \%) & 4 & 4(100 \%) \\ \text { E } & 16 & 3(19 \%) & 18 & 6(33 \%) \\ & 162 & 15(9 \%) & 50 & 12(24 \%)\end{array}$

The farm used feedingstuffs from two different sources-pig fattening meal from mill no. 1 for the pigs, and layer mash from mill no. 2 for the poultry. Both mills were visited and the feedingstuffs of the same batch as used on the farm, and their ingredients, were sampled separately (Table 5). Salmonellae were isolated from the finished products sampled at the mills, and also from bone flour and Angolan fish meal from mill no. 1 and from Angolan fish meal from mill no. 2. The predominant salmonella types found in Angolan fish meal and in pig-fattening meal in mill no. 1 were Salm. infantis and Salm. schwarzengrund; the same types as those found in pigs at the farm and at the bacon factory.

Salm. infantis was not isolated from the layer mash of mill no. 2, and the 
organisms found in the meat of the eggs produced may well have passed to the poultry from the pig meal which was distributed to the pigs in the same bucket as that used for the poultry feed.

The mixed products contained $3 \%$ of Angolan fish meal and less than $1 \%$ of bone flour (in some batches less than $0 \cdot 1 \%$ ). This difference in the proportions of the ingredients could explain the predominance of the salmonella types found in fish meal among the salmonella organisms isolated from the final product.

Table 5. Salmonellae in animal feedingstuffs used on farm $D$. Number of salmonella isolations

\begin{tabular}{|c|c|c|c|c|c|c|c|}
\hline \multirow[b]{3}{*}{ Salmonella type } & \multirow{3}{*}{$\begin{array}{l}\text { Pig. } \\
\text { fattening } \\
\text { meal } \\
\text { taken } \\
\text { at } \\
\text { Farm D }\end{array}$} & \multicolumn{3}{|c|}{$\begin{array}{l}\text { Pig-fattening meal from } \\
\text { mill } 1\end{array}$} & \multicolumn{3}{|c|}{$\begin{array}{l}\text { Layer mash from } \\
\text { mill } 2\end{array}$} \\
\hline & & & Cons & tuents & & Cons & tuents \\
\hline & & Mixed & $\begin{array}{l}\text { Bone } \\
\text { flour }\end{array}$ & $\begin{array}{c}\text { Angolan } \\
\text { fish } \\
\text { meal }\end{array}$ & Mixed & $\begin{array}{l}\text { Bone } \\
\text { flour }\end{array}$ & $\begin{array}{c}\text { Angolan } \\
\text { fish } \\
\text { meal }\end{array}$ \\
\hline Salm. agama & 1 & 2 & 5 & - & - & - & - \\
\hline Salm. albany & - & - & - & 5 & - & - & - \\
\hline Salm. bareilly & - & 1 & - & - & - & - & - \\
\hline Salm. braenderup & - & - & - & - & 2 & - & - \\
\hline Salm. cerro & - & - & - & 3 & - & - & - \\
\hline Salm. goerlitz & - & - & - & 1 & - & - & - \\
\hline Salm. havana & - & - & 2 & - & - & - & - \\
\hline Salm. infantis & 3 & 5 & - & 4 & - & - & - \\
\hline Salm. kentucky & - & 1 & - & - & - & - & - \\
\hline Salm. orion & - & 1 & - & 4 & 1 & - & 3 \\
\hline Salm. schwarzengrund & - & 6 & - & 8 & - & - & - \\
\hline Salm. tennessee & - & - & 1 & - & - & - & - \\
\hline No. samples taken & 4 & 12 & 10 & 17 & 10 & 10 & 5 \\
\hline $\begin{array}{l}\text { No. salmonella } \\
\text { isolations }\end{array}$ & 4 & 16 & $8^{*}$ & $25 \dagger$ & 3 & 0 & 3 \\
\hline
\end{tabular}

\section{Farm $E$}

Salm. orion was isolated from both the caecal swab and caecal faeces from one pig in the second series examined at the slaughterhouse. This animal was the first one which had been traced back to a large pig producer, but when the farm was visited there was an interval of 3 weeks between the isolation of this sero-type at the slaughterhouse and the visit.

The farm was a large efficient unit with modern facilities and contained about 1000 pigs. Breeding stock were not kept and weaners were bought from a wide area. There had been no outbreaks of scour or other illness in the preceding 12 months. Pig feedingstuffs were mixed, from bulk supplies of the ingredients, by machinery in a special feed room. The ingredients were ordered weekly and at the time of the visit no samples were available of the particular batches used for the meal fed to the pigs we examined at the bacon factory.

Rectal swabs were taken from sixteen of the pigs on the farm, and from three of the swabs Salm. binza, Salm. newington and Salm. thomasville were isolated. 
Three samples of meal were taken from the feeding troughs and Salm. newington was isolated from the pen of the animal whose rectal swab contained this organism. Salm. binza (2), Salm. thomasville (2), and an unidentified type belonging to Salmonella Group $E$, were found in fifteen samples of Angolan fish meal in the mealmixing room.

Although the investigations at this farm showed a relationship between the salmonella sero-types excreted by the pigs at that time to the sero-types in the infected fish meal then being fed to them, the lapse of time between the original investigation and the present series of examinations was too great for satisfactory results, such as were obtained in the case of Farm D.

\section{DISCUSSION}

For some time it has been known that meat products, and especially pork products, are often contaminated with Salmonellae. They have frequently been suspected of being the vehicle responsible for human cases of infection. It has been known that a number of animal feedingstuffs imported into the United Kingdom contain a wide variety of salmonella types. However, despite these findings and the investigations of workers such as Marcuse et al. (1957) and Rohde \& Bischoff (1956), who have attempted to connect these two findings, the control of salmonella infection in this country has largely been based upon attempts to control a manto-man spread and to prevent a multiplication of organisms after they are already suspected of being present in a product. This is an inadequate and potentially dangerous policy. If we continue to follow it, it must mean that we shall continue to have apparently sporadic incidents of salmonella infection mainly confined to young children and old or debilitated people, who appear to develop a salmonella illness on the ingestion of small numbers of organisms. Also, we must expect apparently inexplicable explosive outbreaks of infection where multiplication of small numbers of these organisms present in foodstuffs has been allowed to occur because of a possibly temporary failure in food hygiene or food preparation.

In the past, farmers and veterinary officers have ignored the large number of potentially dangerous organisms present in pigs because, on examination, the stock showed no illness or disability.

At the start of this investigation we were informed that Salmonellae, other than Salm. cholerae suis, were rarely, if ever, associated with disease in pigs in Northern Ireland. This investigation has shown that on the farms visited this statement is true, but that both in the abattoirs and on the farms the proportion of animals infected may be as high as $20 \%$.

The results of sampling, at the abattoirs and at the farms, did not indicate that salmonella infections in slaughtered pigs in Northern Ireland were due to crossinfection in the holding pens. The proportion of positive rectal swabs at the farms $(9 \%)$ was greater than a random sample of caecal swabs taken after slaughter $(2 \%)$, but lower than the proportion of caecal faeces examined $(23 \%)$.

These differences may well be due to sampling errors or to differences in technique, although it must be emphasized that the farms were selected; the only 
farms visited were those identified as sending infected pigs for slaughter. In deciding to use caecal, rather than rectal, swabs at the bacon factory we were influenced by the fact that the caecal contents are more fluid and easier to sample than faeces from the rectum. Moreover, Galton et. al. (1954) reported a larger number of salmonella isolations from the caecum than the rectum.

The examination of the food eaten by these animals on the farms, and of the feedingstuffs at the mills before delivery, shows that the same salmonella types are present in both places. As these types are new to Northern Ireland it is unlikely that any explanation of the infection, other than direct passage of the organisms from animal food to animal, is possible. Two types of animal feedingstuffs were found to be heavily contaminated-bone flour and fish meal. The predominant organisms in pigs were also those found in the fish meal. The explanation for this selection is probably the large quantity of this substance used in most feedingstuffs and the small number of types found in bone flour is probably due to the small quantity of this constituent which is added.

Salm. orion was isolated from the caecal faeces of eight pigs at the bacon factory, but was not found in the rectal swabs taken from any of the pigs at the farms visited, although it was present in some samples of the fish meal examined. Experience has shown that the distribution of the great variety of salmonella sero-types found in Angolan fish meal is very irregular; one batch may be heavily contaminated with a type that cannot be demonstrated in the next batch. Indeed, different samples from the same batch may yield inconsistent results. By analogy with the human feeding experiments with salmonella organisms (McCullough \& Eisele, $1951 a, b)$ it would seem that infection rates in pigs would be partly a question of dosage which might also be related to the period of excretion. A small infecting dose might result in excretion for a short period, but precise information on this point is not available.

At the same time it would appear that certain animal species provide a more favourable environment for the survival and multiplication of a particular salmonella sero-type than others. For example, if both Salm. infantis and Salm. orion are introduced in the feedingstuffs of a farm keeping poultry and pigs there seems to be a tendency for the pigs to display selective action towards Salm. orion and for the poultry to offer favourable ground to Salm. infantis. The selective action of poultry towards Salm. infantis has also been noted by Hirsch \& Sapiro-Hirsch (1958) and Staack (1958). Recognition of this phenomenon may be of value in the investigation of an outbreak due a to particular sero-type, but with the great multiplicity of salmonella types it obviously has its limitations.

Salm. infantis is a common salmonella type in eggs sent to Northern Ireland packing stations. In the first eight months of 1958 it was isolated from four out of 171 samples of liquid egg examined and no other sero-types were found. On present evidence Salm. orion could be expected to be found frequently in sausages consumed in Northern Ireland or exported to Great Britain. Human cases associated with these types occurred for the first time in Northern Ireland in 1958. Of the twelve salmonella types isolated from pig and poultry feedingstuffs (see Table 5) only two were isolated from human cases in Northern Ireland between 
1951-57 (Salm. kentucky (2) and Salm. bareilly (1)). Yet in the first eight months of 1958 there have been nine known human incidents where these same types have been isolated (Salm. infantis (3), Salm. kentucky (1), Salm. orion (4) and Salm. schwarzengrund (1)). Two of the Salm. infantis incidents were connected with the consumption of uncooked and lightly cooked egg products; two of the Salm. orion incidents followed the consumption of pork sausages; and at least one other incident took place on a farm raising pigs.

The time lag between the introduction of a specific batch of feedingstuff and the passage of its salmonella content through animals to humans is at least some months, and it is not possible to trace the organism back from a human case to its entry into the country. However, one can trace the path of organisms forward from feedingstuffs to human food, and any further evidence of the cycle of these organisms will have to be collected in this way.

Salmonellae can pass directly from an infected fowl to a human by eggs, as was shown in Farm D. The path from an infected pig to a susceptible person is more indirect. Only one of the thirty meat samples examined at the slaughterhouse was shown to contain a salmonella organism. This may indicate that only a minor surface contamination had occurred, the failure of the isolation procedures to pick up small numbers of organisms, or reinforce the evidence that few of these salmonellae carried in the intestines invade the tissues.

However, even in an efficient and modern abattoir some of the organisms pass into the packaging part of the organization and the finding of $70 \%$ of sausagemeat samples contaminated with $\mathrm{Salm}$. orion probably represents the contamination of the sausage-making machinery by organisms present in the pigs before their arrival for slaughter.

There is a major difference between our findings and those of McDonagh \& Smith (1958); they found Salm. typhimurium in $36 \%$ of infected pigs in Bradford. It has already been noted that Salm. typhimurium is less frequently isolated in Northern Ireland than in England and Wales, and it was not isolated from pigs in our study. This difference is unexplained and needs further investigation as it is unlikely to be due only to a difference in the proprietary feedingstuffs used.

A variety of investigations have shown that salmonella organisms of significance to humans are being imported into the United Kingdom and are passing into foods sold for human consumption. This is not the fault of the farmer, the veterinary officer, the food processing factory, the abattoir or the food retailer. These organisms will continue to be passed to humans unless it is recognized that the only effective place to break the chain of infection is by attempting to break the animal cycle. This is possible in some instances by the bacteriological control of animal feedingstuffs, and should be the concern of both the Health and the Veterinary Authorities. In Northern Ireland a start should be made now by preventing the sale of animal feedingstuffs, such as Angolan fish meal, known to be heavily contaminated with a great variety of salmonella types, and substituting alternatives which are available and which have been shown to be bacteriologically preferable. 


\section{SUMMARY}

1. Salmonella incidents in Northern Ireland from 1951-58 are compared with the published findings in England and Wales.

2. Caecal swabs from 489 pigs killed in two bacon factories showed a salmonella isolation rate of $2 \%$.

3. Salmonella organisms were isolated from twenty-three out of 100 samples of caecal faeces and from only six of 100 caecal swabs taken from the same animals. Three per cent of meat samples from these pigs and $70 \%$ of sausage samples from this meat contained Salmonellae.

4. Rectal swabs from 162 pigs on five farms producing infected pigs showed Salmonellae in $9 \%$ of those examined.

5. Twenty-four per cent of pig-meal samples taken on these farms contained Salmonellae, and the same salmonella types were found in the meal at the mill and in fish meal and bone meal before mixing.

6. It is probable that some salmonella types pass from feedingstuffs through pigs to human food and cause human infections.

We should like to express our thanks to Dr Joan Taylor of the Salmonella Reference Laboratory, Colindale, for typing many of the Salmonellae; to $\mathrm{Mr} \mathrm{J}$. Stuart of the Veterinary Division, Ministry of Agriculture, Northern Ireland, for help in sampling at an abattoir and on the farms; to the staff of the Northern Ireland Hospitals Authority, Central Laboratory, for technical assistance; to Mr J. Patton and Dr D. Luke for much help and advice at many stages of this inquiry; to Miss A. McCann for the secretarial work; to the Northern Ireland Hospitals Authority for a grant towards the expenses in 1958; and to our colleagues in the Local Authorities, General Practice, on the farms and in the factories who were always most helpful and co-operative.

\section{REFERENCES}

Ewards, P. R. \& Bruner, D. W. (1943). J. infect. Dis. 72, 58.

Galton, M. M., Smith, W. V., McElrath, H. B. \& Hardy, A. B. (1954). J. infect. Dis. $96,236$. Hirsch, W. \& Sapiro-Hmisch, R. (1958). Harefuah, 54, no. 3, 57.

Hоввs, B. C. (1957). Sanitarian, 66, 95.

Hobis, B. C. \& Alutson, V. D. (1954). Monthly Bull. Minist. Hlth Lab. Serv. 4, 63.

Hobbs, B. C., Krng, G. J. G. \& Aluison, V. D. (1945). Monthly Bull. Minist. Hlth Lab. Serv. 4, 40.

Hormaeche, E. \& Salsamendi, R. (1936). Arch. urug. Med. 9, 665.

LeIfson, E. (1935). J. Path. Bact. 40, 581.

Lundbeck, H., Plazikowskt, U. \& Silverstolpe, L. (1955). J. appl. Bact. 18, no. 3, 535.

MacCready, R. A., Reardon, J. P. \& Saphra, I. (1957). New Engl. J. Med. 256, 1121.

McCullough, N. R. \& Eisele, C. W. (1951a). J. infect. Dis. 88, 278.

McCullodgh, N. R. \& Ersele, C. W. (1951b). J. infect. Dis. 89, 209.

MoDonage, V. P. \& Smrth, H. G. (1958). J. Hyg., Camb., 56, 2, 271.

Marcuse, K., Henze, B. \& Pohte, H. D. (1957). Zbl. Bakt. I. Abt. Orig. 169, 493.

Report (1947). Spec. Rep. Ser. med. Res. Coun., Lond., no. 260.

REPORT (1950a). Mon. Bull. Minist. Hlth Lab. Serv. 9, 148.

Report (1950b). Mon. Bull. Minist. Hlth Lab. Serv. 9, 254.

RePORT (1951). Mon. Bull. Minist. Hlth Lab. Serv. 10, 228. 
Report (1954). Mon. Bull. Minist. Hlth Lab. Serv. 13, 12.

Repont (1955a). Mon. Bull. Minist. Hlth Lab. Serv. 14, 34.

Repont (1955b). Mon. Bull. Minist. Hlth Lab. Serv. 14, 132.

RePort (1955c). Mon. Bull. Minist. Hlth Lab. Serv. 14, 203.

Repont (1956). Mon. Bull. Minist. Hlth Lab. Serv. 15, 263.

Rohde, R. \& Bischoff, J. (1956). Zbl. Bakt. I. Abt. Ref. 159, 145.

ScotT, W. M. (1940). Proc. Roy. Soc. Med. 33, 366.

StaACK, H. H. (1958). Arch. Hyg., Berl., 142, part 2, 105.

W ALKER, J. H. C. (1957). Lancet, ii, 283.

(MS. received for publication 21. x. 58) 